\section{Медико- соціальні аспекти глоба^ьного потепління}

\author{
В.І. Цимбалюк', С. Н. Вадзюк²
}

${ }^{1}$ Національна академія медичних наук України, вул. Гериена, 12, Київ 04050, Україна

${ }^{2}$ Тернопільський начіональний медичний університет ім. І. Я. Горбачевського МОЗ України, Майдан Волі, 1, Тернопіль 46001, Україна

роблема глобального потепління останнім часом дедалі більше привертає увагу. За даними Всесвітньої метеорологічної організації, останні чотири роки стали найтеплішими в історії столітніх спостережень, що є яскравою ознакою зміни клімату, що й досі триває. Зазначено, що внаслідок цього дедалі частіше спостерігаються різноманітні кліматичні катаклізми (зливи, тайфуни, шторми, повені та ін.). Причину змін клімату вбачають у накопиченні в атмосфері парникових газів. За таких умов у найбільш невигідному становищі опинились міста, кількість населення яких дедалі збільшується. Вони страждають від так званого ефекту теплового острова. Мовиться також, що зміна клімату впливає на здоров'я жителів планети, тривалість їх життя. Надзвичайно чутливими до загроз, пов'язаних із глобальними змінами клімату, є діти.

Наслідки змін клімату формують певні погодні ситуації, певний погодний фон. Ми, користуючись однією із класифікацій погоди, встановили частоту, з якою зустрічалися ㄲi різні типи упродовж 25-річного періоду в умовах міста Тернополя. Виявилося, що в умовах глобального потепління суттєво зросла кількість днів 3 III типом погоди. Тому щодо питання про вплив сучасних кліматичних умов на здоров'я людей $є$ слушним встановлення змін життєдіяльності за цих метеорологічних ситуацій. Оцінка психоемоційного стану молодих осіб показала погіршення настрою, психічної активності, інтересу до виконання розумової роботи, зростання тривожності за III типу погоди. За цього типу погоди також погіршуються увага, пам’ять, розумові здібності, зростає латентний період складної зорово-моторної реакції. Дослідження фізичної працездатності плавців показало її зниження за метеоситуації III типу. Дихальна система у молодих здорових осіб у разі III типу погоди реагувала зменшенням прохідності бронхів, iï резервних можливостей, погіршенням насиченням крові киснем. При цьому спостерігалося зниження функціональних резервів

\title{
Medical and social aspects of global warming
}

\section{Vitalii I. Tsymbaliuk', Stepan N. Vadzyuk ${ }^{2}$}

${ }^{1}$ National Academy of Medical Sciences of Ukraine, 12 Hertsen St., Kyiv 04050, Ukraine

${ }^{2}$ Horbachevsky Ternopil National Medical University, 1 Maidan Voly, Ternopil 46001, Ukraine

T he problem of global warming has been increasingly attracting attention. According to the World Meteorological Organization, the last four years have become the warmest in the history of a century of observations, which is a clear sign of ongoing climate change. As a result, various climatic cataclysms (downpours, typhoons, storms, floods, etc.) are increasingly observed. The climate change is caused by the accumulation of greenhouse gases in the atmosphere. In these circumstances, the most susceptible cities are those occupied by growing population. They suffer from the so-called «heat island effect». Climate change has been described as affecting the health of the planet's population and people's lifespan. Children are extremely sensitive to the threats posed by global climate change.

The effects of climate change create certain weather situations and conditions. Using one of the weather classifications, we determined the frequency with which different weather types occurred during the 25-year period in the city of Ternopil. It turned out that in the context of global warming, the number of days with the type III weather increased dramatically. Therefore, when posing the question of the impact of current climatic conditions on human health, it is quite reasonable to identify changes in life processes in these meteorological situations. An assessment of psychoemotional state of young people showed worsening of mood, mental activity, interest in performing mental work, increasing anxiety in the type III weather. Attention, memory, thinking, and the latent period of complex visual-motor reaction also worsened in this type of weather. A study of the physical performance of swimmers showed its decrease in type III meteosituations. The respiratory system in young healthy individuals in the third type of weather responded by reducing the patency of the bronchi, its reserve capacity, the deterioration of blood oxygen saturation. At the same time, a decrease in the functional reserves of the cardiovascular system against the background of the imbalance of autonomous regulation of cardiac activity was observed. 
серцево-судинної системи на тлі дисбалансу автономної регуляції діяльності серця. Встановлено підвищення вестибулярної чутливості. Зважаючи на отримані результати, вважаємо, що вивчення впливу глобального потепління на організм людей належить здійснювати з урахуванням не тільки одного метеорологічного фактора - температурного, а їх комплексу у вигляді типів погоди. Розглянуто важливі медико-соціальні питання прогнозування продовольчої безпеки, забезпеченості питною водою.

Ключові слова: глобальне потепління; типи погоди; здоров’я.

Для цитування: Цимбалюк ВI, Вадзюк СН. Медико-соиіальні аспекти глобального потепління. Журнал Національної академії медччних наук України. 2019;25(4):439-47.

DOI: 10.37621/JNAMSU-2019-4-439-447.

Стаття надійшла до редакції 28 жовтня 2019 року

Направлена на рецензування 22 листопада 2019 року

Прийнята до друку 24 грудня 2019 року

\section{ВІДОМОСТІ ПРО АВТОРІВ}

Цимбалюк Віталій Іванович - президент НАМН України, А.М.Н., проф., акад. НАМН України, чл.-кор. НАН України, ORCID: 0000-0001-7544-6603

Вадзюк Степан Несторович - завідувач кафедри фізіології з основами біоетики та біобезпеки Тернопільського НМУ ім. І. Я. Горбачевського, д.м.н., проф., ORCID:0000-0001-9105-8205
An increased vestibular sensitivity was revealed. Based on the obtained results, we believe that the study of the effect of global warming on the human body should be carried out taking into account not only one meteorological factor - temperature, but their complex in the form of weather types.

Important medical and social issues of food security forecasting, drinking water supply are considered.

Keywords: global warming, types of weather, health.

For citation: Tsymbaliuk VI, Vadzyuk SN. Medical and social aspects of global warming. Journal of the National Academy of Medical Sciences of Ukraine. 2019;25(4):439-47. DOI: 10.37621/JNAMSU-2019-4-439-447.

The article was received on October 28, 2019

For review, November 22, 2019

Accepted for publication on December 24, 2019

\section{INFORMATION ABOUT AUTHORS}

Vitalii I. Tsymbaliuk - Dr. Sci. (Medicine), Prof., Cor. member of the NAS of Ukraine, Full member of the NAMS of Ukraine, President of the NAMS of Ukraine, ORCID:0000-0001-7544-6603

Stepan N. Vadzyuk -- Dr. Sci. (Medicine), Prof., Head of the Department of Physiology, Bioethics and Biosafety of Horbachevsky Ternopil NMU, ORCID:0000-0001-9105-8205

\section{Stepan N. Vadzyuk \\ ORCID:0000-0001-9105-8205 \\ vadzyuk@tdmu.edu.ua}

\section{ПРОЯВИ ТА ПРИЧИНИ ГЛОБАЛЬНОГО ПОТЕПЛІННЯ}

Ми є свідками кліматичних катаклізмів, які щороку дедалі більше посилюються. Основним показником, що свідчить про зміну клімату, є середньорічне зростання температури повітря.

Відповідно до висновків міждержавної групи експертів 3 питань зміни клімату, за період з 1880 по 2012 рік підвищення глобальної середньої температури приземного повітря на континентах і океанах становить $0,85^{\circ} \mathrm{C}[1,2]$. За даними Всесвітньої метеорологічної організації, останні чотири роки (2015-2018) стали найтеплішими в історії столітніх спостережень, що є яскравою ознакою триваючої довгострокової зміни клімату. А серпень 2018 року був одним з найспекотніших місяців у світі. Від спеки найбільше постраждала Південна та Північна Європа, Австралія і Південна Африка. Сильні зливи спостерігалися в Китаї, Індії, де під водою опинилися великі території. Смертоносні тайфуни в Японії і Кореї. На Гавайські острови «налетів» тропічний шторм $[3,4,5,6,7,8]$.

Український гідрометеорологічний центр, на кінець 2018 року встановив підвищення середньорічної температури повітря в Україні на $1,1{ }^{\circ} \mathrm{C}$. Останніми роками майже вдвічі зросла повторюваність днів із максимальними тем- пературами влітку, що перевищують 30 та навіть 40 C, які відносяться до екстремальних погодних явищ. Внаслідок цього на переважній частині території України вже спостерігається тенденція посилення посух, збільшення кількості та тривалості спекотних періодів (так званих «теплових хвиль») та посилення пожежної небезпеки. Зросла повторюваність та інтенсивність гроз, сильних злив, граду, шквалів. На півдні України появилися смерчі. Екстремальні явища погоди іноді фіксуються у нетипові для них місяці і сезони, а також поширюються на території, де не спостерігались раніше. Взимку зросли загрози, пов'язані із сильними снігопадами, налипанням мокрого снігу, ожеледицею [9].

За цих умов у найбільш невигідному становищі опинились міста. Вони страждають від так званого ефекту теплового острова. При цьому у містах температура повітря може бути на $10{ }^{\circ} \mathrm{C}$ вищою, ніж у передмісті, навколишніх місцевостях $[10,11]$. Цей ефект обумовлений високим тепловим поглинанням темними брукованими поверхнями та будівлями, теплом, що виділяється від транспортних засобів та кондиціонерів, нестачею рослинності, дерев та поганою вентиляцією $[12,13]$. При цьому слід врахувати, що зараз близько 50 \% населення світу проживають у містах, а до 2050 року ця кількість збільшиться до $68 \%$. 
Причину змін клімату вбачають у нагромадженні в атмосфері так званих парникових газів, тобто газів, що відбивають до поверхні Землі іiі теплове випромінювання. Виділяють парникові гази прямої дії: вуглекислий газ, метан, закис азоту. Крім цього $є$ парникові гази непрямої дії. Вони запускають хімічні реакції в атмосфері з утворенням речовин, що посилюють парниковий ефект.

Атмосферний вуглекислий газ збільшився приблизно 3 28 \%, до початку промислової революції, до 40 \% у квітні 2013 року [14]. Це збільшення у першу чергу є результатом від спалювання викопного палива. Вирубування лісів також впливає на атмосферу землі, зменшуючи поглинання вуглецю рослинами [15]. Приблизно половина загального приросту вуглекислого газу відбулася за останні 40 років [16]. Здатність до теплозатримання (парниковий ефект) вуглекислого газу та інших газів було визнано ще на початку XVIII століття [17].

\section{ВПЛИВ ГЛОБАЛЬНОГО ПОТЕПЛІННЯ НА ЗДОРОВ'Я ЛЮДЕЙ}

Зміна клімату впливає на здоров'я прямими і непрямими шляхами. Прямі наслідки зміни клімату на здоров'я включають ті, що відносяться до перепадів температури, екстремальних погодних явищ та впливу ультрафіолетового випромінювання. До непрямих наслідків належать ті, що опосередковуються через природні чи людські системи, такі наприклад як закономірні захворювання органів дихання від змін якості повітря та алергенів [18].

Високі температури є загрозою для здоров'я людини. Так, понад 70000 додаткових смертей трапилося в Європі в гарячі періоди літа 2003 року, порівняно з періодом 1998-2002 років [19]. Особливо небезпечним є поєднання екстремальних впливів максимальних температур і теплих нічних температур [20]. У Берліні вищий рівень смертності спостерігався в густо забудованих районах порівняно 3 сільськими [21].

Люди похилого віку вразливіші до впливу теплових хвиль, частково через погіршення фізичного здоров'я та впливу когнітивних порушень щодо сприйняття ризику для здоров’я, пов'язаного з теплом [22]. Однак смертність від високої температури також значна серед молодого населення, за літературними даними, особливо в містах Східного i Південного Середземномор'я, включаючи Стамбул та Тель-Авів [23].

Очікується, що температура влітку, а також частота і сила теплових хвиль зростатимуть в міру зміни клімату [24]. Середземноморські країни будуть особливо потерпати від екстремальних температур. Очікується, що кількість теплових хвиль збільшиться до 45 днів за літо до кінця XXI століття [20].

Одним із наслідків теплових хвиль є пожежі. У середньому в Європі щороку трапляється приблизно 70000 пожеж, що охоплюють понад півмільйона гектарів лісових земель. Приблизно 70 \% пожеж трапляється в середземноморському регіоні [25]. У проміжку між 2007 та 2014 роках при ліквідації пожеж загинуло 225 людей [26]. Вплив пожеж на здоров'я призводить до прямого впливу вогню та диму, але також опосередковано через порушення роботи медичних закладів, транспортної інфраструктури, екологічні зміни [27]. 3 огляду на сильний руйнівний характер, пожежі та їх наслідки можуть спричиняти значні психологічні негаразди, як в короткостроковій, так і в довгостроковій перспективі [28].

Пожежі також $€$ важливим джерелом забруднюючих повітря речовин, включаючи тверді частинки [29], летючі органічні сполуки та оксиди азоту та сірки, продукти, які можуть викликати алергічні та респіраторні захворювання. Викиди диму можуть поширюватися на сотні кілометрів за вітром піддаючи багатьох людей шкідливій суміші твердих частинок та інших шкідливих компонентів [30,31]. Згідно з нещодавньою оцінкою дим щорічно у всьому світі викликає до 339000 смертей [32]. Крім того, як підтверджують новітні дослідження, ці забруднювачі повітря відіграють певну роль у продовженні зміни клімату і, отже, збільшують ризики для здоров'я людини [33]. Під час лісових пожеж у 2010 році під Москвою, які сталися в умовах великої теплової хвилі, яка тривала 44 дні було близько 11000 випадків смертей від високої температури та забруднення повітря [34]. Прогнози показують збільшення ризику пожеж у багатьох регіонах, що значною мірою пояснюється скороченням літніх опадів [35].

Якість повітря є важливим чинником стану здоров'я в Європі [36]. Дані показують, що забруднення повітря у європейських містах є причиною значної кількості смертей, особливо при серцево-респіраторних захворюваннях.

Серед екстремальних змін глобального потепління, значне місце належить річковим та прибережним повеням. При цьому ризики для здоров'я дуже різноманітні і включають смертність та захворюваність, спричинені серцево-судинними розладами, утопленнями, ураженнями електричним струмом, травмами, інфекційними захворюваннями та психологічними наслідками [37]. Іншими наслідками можуть бути переселення населення, руйнування інфраструктури, закладів охорони здоров'я, забруднення питної води, продовольчих запасів, знищення сільськогосподарських культур [38, 39].

Висока температура впливає на екосистеми та виникнення кліматично залежних інфекційних захворювань $[18,40]$. Встановлено таких 11 патологій, зростання спалахів яких обумовили кліматичні зміни [41]. Найбільш поширеними серед них є малярія, лихоманка Західного Нілу, Чангунгуня та Данге [42]. Сильні опади та повені збільшують ризик лептоспірозу [43].

Дослідження, проведені у Казахстані, підтвердили прогноз щодо зміни клімату та зростання захворюваності на сальмонельоз внаслідок збільшення кількості опадів $[44,45]$.

Надзвичайно чутливими до загроз пов'язаних із глобальними змінами клімату є діти. Так, у зв'язку із цим 88 \% захворювань виникають у дітей до 5 років [46]. Підвищення температури навколишнього середовища також може збільшити несприятливі наслідки щодо народження, зокрема передчасні пологи та мертвонародження [47, $48,49]$. В одному із досліджень було вказано, що до кінця 21 століття прогнозується, що рівень дитячої смертності може збільшитися на 5,5 \% у дівчаток і на 7,8 \% у хлопчиків через смерть, пов'язану із глобальним потеплінням [50]. 
ТАБЛИЦЯ 1 / TABLE 1

ПОКАЗНИКИ ВИКОНАННЯ КОРЕКТУРНОЇ ПРОБИ ЗА РІЗНИХ ТИПІВ ПОГОДИ $(\mathrm{M} \pm \mathrm{m}, \mathrm{n}=40)$

INDICATORS OF PROOFREADING TEST FOR DIFFERENT TYPES OF WEATHER $(M \pm m, n=40)$

\begin{tabular}{l|c|c|c|} 
Показники / Indicators & \multicolumn{3}{|c}{ Тип погоди / Туре of weather } \\
\cline { 2 - 4 } Кількість переглянутих літер / Number of letters viewed & I & II & III \\
\hline Коефіцієнт працездатності / Coefficient of efficiency & $4288,52 \pm 153,85^{*}$ & $3639,82 \pm 176,67$ & $3178,90 \pm 131,43$ \\
\hline Точність, бали / Асcuracy, points & $23,28 \pm 0,51$ & $22,58 \pm 0,68$ & $21,68 \pm 0,71$ \\
Продуктивність, бали / Efficiency, points & $23,15 \pm 0,52^{*}$ & $21,08 \pm 0,72^{* *}$ & $18,45 \pm 0,75^{* * *}$ \\
\hline Стійкість уваги, бали / Persistence of attention, points & $16,38 \pm 0,34^{*}$ & $15,18 \pm 0,44^{* *}$ & $13,88 \pm 0,42^{* * *}$
\end{tabular}

Примітки: * - p<0,001 (за t-критерієм Стьюдента) при порівнянні I типу погоди з III; * * p < 0,01 (за t-критерієм Стьюдента) при порівнянні II muпу погоди з l; ***-p<0,05 (за т-критерієм Стьюдента) при порівнянні III типу погоди з II.

Notes: * $-p<0.001$ (Student's t-test) when comparing I type of weather with III; * ${ }^{*} p<0.01$ (Student's t-test) when comparing II type of weather with I; $* * *-p<0,05$ (Student's $t$-test) when comparing III type of weather with II.

Діти в найбідніших країнах найбільше потерпають від змін клімату [51].

Посухи, пов’язані зі змінами клімату, є головними проблемами охорони здоров'я, особливо щодо здатності країн з низьким рівнем доходу підтримувати достатнє виробництво продуктів харчування [52]. Недоїдання $є$ основною причиною масових випадків смерті від пневмонії у дітей віком до 5 років [53].

Зміни клімату, як передбачається, збільшать захворюваність у дітей на астму, через пов'язане з цим зростання забруднювачів повітря, включаючи наземний озон. Озон $є$ потужним подразником бронхів, що збільшує захворюваність та смертність від астми [54]. Через більш високу вентиляцію легень, та час проведений на вулиці, діти є групою, найбільш вразливою до озону [55].

Потужні опади та затяжні посухи, пов'язані із глобальним потеплінням, призводять до зростання інфекційних шлунково-кишкових захворювань у дітей молодших 5 років [56]. В основному це бактеріальний гастроентерит $[57,58]$.

Таким чином, вчені основні свої зусилля спрямовують на відстеження джерел та ступеня забруднення повітря, що веде до зростання парникового ефекту та на його тлі екстремальних гіпертермічних явищ, та їх впливу на здоров’я людей. Але висока температура повітря - це лише один метеорологічний елемент, який має вплив на населення Землі у певний календарний проміжок. Тому для більш об'єктивної оцінки впливу глобального потепління на здоров’я людей, на нашу думку, достеменну інформацію про зміну життєдіяльності можна отримати при врахуванні дії комплексу метеорологічних факторів впродовж року.

\section{ЗМІНИ МЕДИКО-МЕТЕОРОЛОГІЧНИХ СИТУАЦІЙ В УМОВАХ ГЛОБАЛЬНОГО ПОТЕПЛІННЯ}

Як відомо, сукупність метеорологічних елементів у певній місцевості в даний момент часу визначає певний тип погоди.

Розрізняють різні медико-метеорологічні типи погоди. У своїх дослідженнях ми користувалися класифікацією К. І. Григор'єва, згідно з якою виокремлюють чотири типи медико-метеорологічних ситуацій: [59]

I ТИП відзначається спокійним ходом основних метеорологічних елементів, за відсутності атмосферних фрон- тів. Атмосферний тиск, температура і вологість мають нормальний добовий хід і змінюються в його межах плавно. Швидкість вітру $0-5 \mathrm{~m} / \mathrm{c}$.

II ТИП відбувається при походженні розмитих атмосферних фронтів; швидкість вітру 7-12 м/с. Улітку можливі невеликі дощі.

III ТИП зумовлюють активні атмосферні фронти; це викликає зміну атмосферного тиску до 4 гПа/3 год, швидкість вітру 15-20 м/с. Можливі різкі зміни температури. Із штормових явищ можуть бути грози, шквали, зливи, хуртовини.

IV TИП спостерігається за активної циклонічної діяльності. Зміна атмосферного тиску перевищує 5 гПа/3 год, швидкість вітру - більше $20 \mathrm{~m} / \mathrm{c}$; спостерігаються грози, шквали, зливи, хуртовини, пилові бурі.

Першим кроком наших досліджень було встановлення частоти 3 якою зустрічалися різні типи погоди кожного року упродовж 25-річного періоду (з 1993 по 2018 рік). Виявилося що на початку 90-х років у 20-25 \% днів року спостерігався I тип погоди, у 60-70 \% - II типу, погода III типу - у 10-15 \%, a IV тип - міг зустрітися як казуїстика впродовж календарного року. В останні роки співвідношення між типами погоди змінилися: зменшилася частка I та II типів погоди, зросла частота погоди III типу до 20-25 \%, а кількість днів з погодою IV типу збільшилася до $10-15$. Це результат спостереження в умовах міста Тернопіль [60, 61, 62].

Таким чином, наші 25-річні спостереження показують, що в умовах глобального потепління зростає кількість днів з III і IV типами погоди. Тому питання щодо впливу сучасних кліматичних умов на здоров'я людей недостатньо вивчене і є доцільним для встановлення змін життєдіяльності за таких метеорологічних ситуацій.

\section{ПСИХОФІЗІОЛОГІЧНІ ОСОБЛИВОСТІ ЗА РІЗНИХ МЕТЕОРОЛОГІЧНИХ СИТУАЦІЙ}

Проведена нами оцінка психоемоційного стану молодих осіб показала погіршення настрою (субдепресії) за III типу погоди порівняно з I. Настрій в осіб з різним рівнем нейротизму, який $є$ вродженою ознакою, змінювався залежно від погоди неоднаково. В обстежуваних з низьким та середнім нейротизмом рівень субдепресії залишався 
ТАБЛИЦЯ 2 / TABLE 2

ЗМІНИ ОБ'ЄМУ ТА ПЕРЕМИКАННЯ УВАГИ ЗА РІЗНИХ МЕТЕОСИТУАЦІЙ $(M \pm m, n=45)$ / CHANGES IN VOLUME AND SWITCHING OF ATTENTION IN DIFFERENT WEATHER SITUATIONS $(\mathrm{M} \pm \mathrm{m}, \mathrm{n}=45)$

\begin{tabular}{c|c|c} 
Тип погоди / Type of weather & $\begin{array}{c}\text { O6'єм уваги, бали / } \\
\text { Volume of attention, points }\end{array}$ & $\begin{array}{c}\text { Перемикання уваги, бали / } \\
\text { Switching attention, points }\end{array}$ \\
\hline I & $13,82 \pm 0,41^{* *}$ & $15,22 \pm 0,31^{* * *}$ \\
II & $13,40 \pm 0,39^{* *}$ & $14,33 \pm 0,38^{* * *}$ \\
III & $12,31 \pm 0,36$ & $12,25 \pm 0,27$
\end{tabular}

Примітки: * - p<0,05 (за t-критерієм Стьюдента) при порівнянні II типу погоди з III; ** - P<0,01 (за t-критерієм Cтьюдента) при порівнянні I muni погоди з III; *** - $P<0,05$ (за t-критерієм Стьюдента) при порівнянні I та II типів погоди з III.

Notes: * $-p<0.05$ (Student's t-test) when comparing II type of weather with type III; ** $-p<0.01$ (by Student's t-test) when comparing the I type of weather with the III; *** $-p<0.05$ (by Student's t-test) when comparing I and II types of weather with III.

відносно стабільним, а група осіб з високим нейротизмом показала суттєве субдепресивне погіршення настрою за III типу погоди [62].

За III типу погоди встановлено достовірне, порівняно 3 I типом, погіршення таких показників, як психічна активність, інтерес до виконання розумової роботи та емоційний тонус, а порівняно з II типом, достовірно погіршувався інтерес до виконання розумової роботи та емоційний тонус [62].

При визначенні ситуаційної тривожності за Спілбергером встановили іï зростання за III типу погоди, особливо в осіб з високим нейротизмом [62].

Дослідження уваги показало, (табл. 1), що кількість переглянутих літер під час виконання коректурної проби, була вищою при метеоситуації І типу, порівняно з III. Коефіцієнт працездатності та продуктивність уваги знижувалися за II та III типів погоди. Щодо точності виконання завдання, то спостерігалася тенденція до ії зниження за III типу погоди. Стійкість уваги була найбільшою при I типі погоди, знижувалася за II типу і була найменшою за III типу [62].

Обсяг уваги (табл. 2) за I типу погоди достовірно переважав такий за III типу. В умовах II типу погоди досліджуванні залишався практично на рівні I типу медико-метеорологічної ситуації і тому відповідно був також більшим порівняно з III типом. Аналогічні зміни відбувалися і $з$ перемиканням уваги (табл. 2).

При вивченні процесів мислення доведено негативний вплив погоди III типу на них.

Таким чином, отримані дані свідчать, що розумова працездатність за метеоситуацій III типу, кількість яких
Рис. 1. Зміни показника пам'яті в осіб з низьким (а), середнім (б) та високим (в) нейротизмом залежно від погоди.

Fig. 1. Changes in memory index in individuals with low (a), medium (b), and high (c) neuroticism depending on the weather.

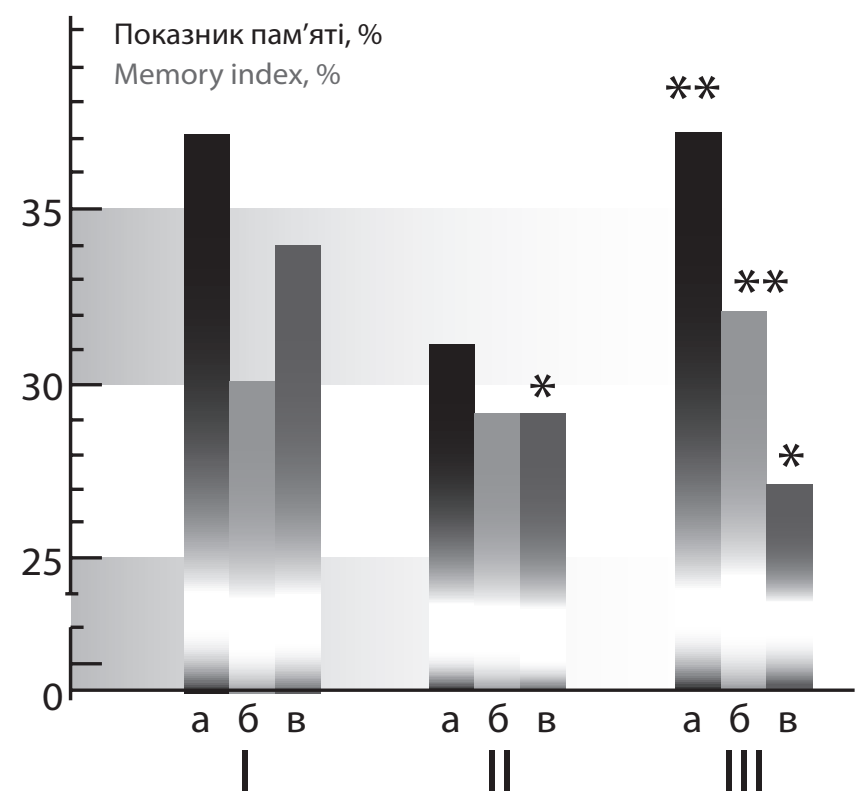

Примітки: * - $<<0,05$ для II та III типу погоди в порівнянні з I; ** $-p<0,05$ для осіб з низьким та середнім нейротизмом порівняно з особами із високим нейротизмом у разі несприятливої погоди.

Notes: * $-p<0,05$ for II and III type of weather compared to I; ** $-p<0.05$ for people with low and moderate neuroticism compared with people with high neuroticism in adverse weather.

\section{ТАБЛИЦЯ 3 / TABLE 3}

ЛАТЕНТНІ ПЕРІОДИ ЗОРОВО-МОТОРНИХ РЕАКЦІЙ ТА КІЛЬКІСТЬ ПОМИЛОК ЗА РІЗНИХ ТИПІВ ПОГОДИ (М $\pm \mathrm{m}) /$ LATENCY PERIODS OF VISUAL-MOTOR REACTIONS AND THE NUMBER OF ERRORS IN DIFFERENT TYPES OF WEATHER $(\mathrm{M} \pm \mathrm{m})$

\begin{tabular}{c|c|c|c|}
\hline $\begin{array}{c}\text { Тип погоди / } \\
\text { Type of weather }\end{array}$ & $\begin{array}{c}\text { Проста зорово-моторна } \\
\text { реакція, мc / Simple visual- } \\
\text { motor response, ms }\end{array}$ & $\begin{array}{c}\text { Складна зорово-моторна } \\
\text { реакція, мc / Complex visual- } \\
\text { motor response, ms }\end{array}$ & $\begin{array}{c}\text { Кількість помилок / } \\
\text { Number of errors }\end{array}$ \\
\hline I $(\mathrm{n}=30)$ & $132,21 \pm 6,86$ & $230,91 \pm 10,18^{*}$ & $0,70 \pm 0,16^{*}$ \\
II $(\mathrm{n}=30)$ & $135,62 \pm 7,14$ & $227,54 \pm 11,14^{*}$ & $1,07 \pm 0,17^{*}$ \\
III $(\mathrm{n}=30)$ & $146,01 \pm 6,69$ & $266,45 \pm 8,71$ & $1,60 \pm 0,20$
\end{tabular}

Примітки: * - p<0,05 (за t-критерієм Стьюдента) при порівнянні I та II типів погоди з III.

Notes: $1 .{ }^{*}-p<0,05$ (Student's t-test) when comparing I and II types of weather with III. 
в умовах глобального потепління зростає, погіршується. Тобто у сучасних кліматичних умовах всі види суспільної діяльності, які потребують уваги, доброї пам'яті та ефективного мислення, з урахуванням виявлених психоемоційних змін, сумарно за рік не будуть мати належного підгрунтя для їх очікувано-належної реалізації. А це, вочевидь, призведе до виникнення стресів та зростання на їх основі різних захворювань.

У процесі життя людина певним чином реагує на сигнали зовнішнього середовища. Її пристосування до впливу довкілля залежить від швидкості реакції. Ось чому вимірювання часу реакції у відповідь на певний сигнал має важливе практичне значення.

Латентний період простої зорово-моторної реакції (табл. 3) в обстежуваних суттєво не змінювався за жодного типу погоди, лише незначно збільшуючись за III типу погоди. Латентний період складної зорово-моторної реакції був коротшим за I і II типів погоди, проте достовірно його значення зростало за III типу (табл. 3). Кількість помилок також суттєво зростала за III типу погоди [62].

Таким чином, проведені нами дослідження стану уваги показали, що за III типу погоди спостерігається іï погіршення.

Дуже важливою функцією вищої нервової діяльності людини є пам'ять, яка забезпечує фіксацію та відтворення отриманої інформаціі. Дослідження короткотривалої зорової пам'яті в осіб з різним ступенем нейротизму показало, що найбільш чутливими до змін погоди були особи з високим нейротизмом (рuc. 1). У них спостерігалося достовірне зниження показника зорової пам'яті як за II, так і за III типу погоди, порівняно з I. Проте найбільш суттєві зміни мали місце за III типу погоди [62].

Проведені нами дослідження фізичної працездатності у плавців оздоровчої групи, третього і другого розрядів показали в цілому їі зниження за метеоситуації III типу. Проте регулярні фізичні навантаження у водному середовищі $€$ ефективним способом підвищення стійкості організму людини до несприятливих впливів метеофакторів [63].

Отримані нами у 2005-2006 рр. дані щодо зміни фізичної працездатності за різних метеоумов знайшли підтвердження у працях китайських вчених, оприлюднених у 2018 році Вони заявили, що глобальне потепління веде до зниження працездатності населення [64].

Глобальне потепління сприяє підвищенню концентрації пилу та алергенів у повітрі [8]. Це може спровокувати розвиток різних захворювань дихальної системи. I дійсно наші дослідження показали, що у молодих здорових осіб за III типу погоди спостерігається зменшення прохідності бронхів, перебудова патерну дихання за тахіпноїчним типом, зменшення резервних можливостей дихальної системи, погіршення насичення крові киснем [65].

Таким чином, в умовах глобального потепління $є$ як зовнішні, так і внутрішні умови для зростання захворювань дихальної системи.

Щодо функціонування системи кровообігу у практично здорових молодих осіб за метеоситуації III типу, то нами встановлено зниження функціональних резервів серцево-судинної системи, на тлі дисбалансу автономної регуляції діяльності серця [66].
Це також дає підстави прогнозувати зростання захворювань серцево-судинної системи.

За III типу погоди зростає кількість осіб із підвищеною вестибулярною чутливістю. У 57 \% осіб, в яких за I типу погоди показник вестибулярної стійкості мав рівень «достатня стійкість», то за III типу він знизився до рівня «недостатня вестибулярна стійкість». Наслідком цього може бути ціла низка функціональних розладів: кінетози, запаморочення, затьмарення, порушення ортостатики та інше, а також розвиток гіпертонічної хвороби [67].

3 вищевикладеного випливає, що в напрямку вивчення впливу глобального потепління на здоров'я людей може бути прийнятним дослідження психофізіологічних особливостей, розумової та фізичної працездатності, виникнення і протікання захворювань, їх лікування і попередження у взаємозв'язку з типами погоди.

\section{ХАРЧОВА БЕЗПЕКА ПРИ ГЛОБАЛЬНОМУ ПОТЕПЛІННІ}

Важливим медико-соціальним питанням є стан харчування. У зв’язку зі змінами клімату прогнозують зниження виробництва харчових продуктів у районах Середземного моря, Південно-Східної Європи та Центральної Азії, де, таким чином, виникне ризик порушення харчової безпеки. До середини XXI століття зниження врожайності в Центральній Азії може сягнути 30 \%, що створить загрозу продовольчої безпеки як в даному регіоні, так і в світі загалом [68].

В умовах глобального потепління буде змінюватися не тільки кількість рослинних продуктів, але і їх якість. Так, вчені Мерілендського університету виявили, що глобальне потепління і збільшення концентрації вуглекислого газу в атмосфері Землі приведе до значного зменшення здатності рослин поглинати азот і нагромаджувати його сполуки в їстівних плодах, а відповідно погіршуватиметься їх розвиток. Крім цього, зниження доступу до азоту у рослин негативно відобразиться на травоїдних тваринах, а це, своєю чергою, погіршуватиме харчову безпеку [69].

Ще одним негативним наслідком глобального потепління стає брак питної води. За оцінками ООН, сьогодні п’ята частина жителів планети, або 2,6 мільярда людей, не має доступу до чистої питної води. Приблизно 39 країн світу отримують більшу частину необхідної їм води 3-за кордону. Прогнозується, що до 2080 року ця проблема торкнеться додатково 16-44 млн осіб у Центральній і Південній Європі, а також в Центральній Азії. На мапі Європи Україна вважається маловодною країною, оскільки більшість наших водних ресурсів через забруднення не придатні до водозабору питної води.

Останні проведені дослідження на замовлення Світового банку поставили нас за кількістю питної води на душу населення на 125 місце із 180 країн. Ми перебуваємо десь між Чадом і Суданом, африканськими країнами. А якщо говорити про Херсонську область, то там кількість питної води взагалі менша, ніж в центральній частині країни, більш ніж удвічі. В Україні ця проблема може гостро постати вже з 2025 року.

У зв'язку із наведеними медико-соціальними ризиками та аналізу міжнародних звітів вже до 2050 року на планеті може бути до 250 млн «кліматичних» біженців [69]. 


\section{ПРОТИДІЯ НЕГАТИВУ, ПОВ'ЯЗАНОМУ ЗІ ЗМІНАМИ КЛІМАТУ В УКРАЇНІ}

Наведені дані - це тільки частина медико-соціальних проблем, які будуть загострюватися із поглибленням глобального потепління. Тому нам треба оперативно й адекватно впливати на основні ланки, які перешкоджають або сприяють адаптації людей до змін клімату.

Варто зазначити, що Україна як європейська держава не лишається осторонь від проблем, пов'язаних із глобальним потеплінням. Так, розпорядженням Кабінету Міністрів України від 7 грудня 2016 року № 932 схвалена «Концепція реалізації державної політики у сфері зміни клімату на період до 2030 року» та розроблено план захо- дів щодо ії реалізації, виконання яких контролюється Верховною Радою України.

Відповідно до п. 18 розпорядження Кабінету Міністрів України «Про затвердження плану заходів щодо виконання Концепції реалізації державної політики у сфері зміни клімату на період до 2030 року» від 6 грудня 2017 року № 878-р Міністерство охорони здоров’я України має розробити та затвердити протягом 2019-2020 років План заходів щодо адаптації населення до зміни клімату.

Національна академія медичних наук України готова долучитися до його створення та розробляти заходи щодо запобігання негативних наслідків глобального потепління задля досягнення кінцевої мети - збереження здоров’я нації.

\section{СПИСОК ВИКОРИСТАНИХ ДЖЕРЕЛ / REFERENCES}

1. Hansen J, Ruedy $R$, Sato M and Lo K. Global surface temperature change. Reviews of Geophysics. 2010:48. DOI: 10.1029/2010RG000345.

2. National Academy of Sciences (2010) Advancing the Science of Climate Change. Accessed. 2010 December 1:39.

DOI: $10.17226 / 12782$

3. NASA (2010, January 21). 2009: Second Warmest Year on Record; End of Warmest Decade. Accessed. 2010 November 30:23. Available from: https://www.nasa.gov/topics/earth/features/temp-analysis-2009.html.

4. NASA (2010, January 21). NASA Climatologist Gavin Schmidt Discusses the Surface Temperature Record. Accessed. 2010 November 30:62. Available from: https://www.nasa.gov/topics/ earth/features/gavin-schmidt.html.

5. NASA Earth Observatory (2010, June 3) Fact Sheet: Global Warming. 2010 November 30:37. Available from: https://earthobservatory.nasa. gov/features/GlobalWarming.

6. NASA Goddard Institute for Space Studies (n.d.). GISS Surface Temperature Analysis. Accessed. 2010 November 30:19. Available from: https://data.giss.nasa.gov/gistemp/.

7. NOAA National Climatic Data Center (n.d.). Global Warming Frequently Asked Questions. Accessed. 2010 December 1:56. Available from: https://www.climate.gov/news-features/understanding-climate/global-warming-frequently-asked-questions.

8. NOAA Paleoclimatology. (n.d.) Climate Timeline Tool: Climate Resources for 1000 Years. Accessed. 2010 December 1:74-76. Available from: https://www.ncdc.noaa.gov/data-access/ paleoclimatology-data.

9. Leskov BN, Pirnach GM, Sirota MV, Shpig VM. Tornadoes in Crimea on July 22, 2002. Scientific works of the Ukrainian Hydrometeorological Research Institute. 2011:50-1. Available from: https://ldubgd.edu.ua/sites/default/files/3 nauka/visnyky/visnyk/12/12 20.pdf.

10. Krilova $A B$. Monitoring the formation and development of the «thermal island» of the city of Kiev. Ukrainian Journal of Remote Sensing. 2014;(2):35-7. Available from: https://ujrs.org ua/ujrs/article/view/19.

11. Rogovoj AS. Study of the effect of thermal island in the city of Kharkov.
12. Hajat $S$, Kosatky $T$. Heat-related mortality: a review and exploration of heterogeneity. J Epidemiol Community Health. 2010;64(9):753-60. DOI: 10.1136/jech.2009.087999.

13. O'Neill MSEK: Temperature extremes and health: impacts of climate variability and change in the United States. J Occup Environ Med. 2009;51(1):13-25.

DOI: 10.1097/JOM.0b013e318173e122.

14. Monastersky R. Global carbon dioxide levels near worrisome milestone. Nature. 2013;497(7447):13-4. DOI: 10.1038/497013a.

15. Intergovernmental Panel on Climate Change. Climate Change 2014: Mitigation of Climate Change. New York, NY: Cambridge University Press; 2014. Available from: https:// www.ipcc.ch/report/ar5/wg3/.

16. Intergovernmental Panel on Climate Change. Climate Change 2013: The Physical Science Basis. New York, NY: Cambridge University Press; 2013. Available from: https://www.ipcc. ch/report/ar5/wg1/.

17. Arrhenius S. On the influence of carbonic acid in the air upon the temperature of the ground. Philosophical Magazine and Journal of the Sciences. 1896:41:237-76. DOl: $10.1080 / 14786449608620846$

18. Smith $K$, Woodward A, Campbell-Lendrum $D_{\text {, }}$ Chadee D, Honda Y, Liu Q, Olwoch J, Revich B, Sauerborn $R$. Human health: Impacts, adaptation, and co-benefits. In Climate Change 2014: Impacts, Adaptation, and Vulnerability. Part A: Global and Sectoral Aspects; Cambridge University Press: Cambridge, UK; New York, NY, USA. 2014:709-54. DOI: 10.1016/S0140-6736(14)60576-6.

19. Robine JM, Cheung SLK, le Roy $S$, van Oyen $H$ Griffiths C, Michel JP, Herrmann FR. Death toll exceeded 70,000 in Europe during the summer of 2003. C.R. Biol. 2008;331:171-8. DOI: 10.1016/j.crvi.2007.12.001.

20. Amengual $A$, Homar $V$, Romero $R$, Brooks $H E$, Ramis C, Gordaliza M, Alonso S. Projections of heat waves with high impact on human health in Europe. Glob. Planet Chang. 2014;119:71-84. DOI: 10.1016/j.gloplacha.2014.05.006.

21. Gabriel KMA, Endlicher WR. Urban and rural mortality rates during heat waves in Berlin and Brandenburg, Germany.
Environ. Pollut 2011:159:2044-2050. DOI: 10.1016/j.envpol.2011.01.016.

22. Conti $S$, Masocco M, Meli P, Minelli G, Palummeri E, Solimini $R$, Toccaceli V, Vichi $M$. General and specific mortality among the elderly during the 2003 heat wave in Genoa (Italy). Environ. Res. 2007;103:267-74. DOI: 10.1016/j.envres.2006.06.003.

23. Leone $M, D^{\prime}$ lppoliti $D$, de Sario $M$, Analitis $A$ Menne B, Katsouyanni K, de'Donato FK, Basagana $X$, Salah $A B$, Casimiro E et al. A time series study on the effects of heat on mortality and evaluation of heterogeneity into European and Eastern-Southern Mediterranean cities: Results of EU CIRCE project. Environ. Health Glob. 2013;12:55. DOI: 10.1186/1476-069X-12-55.

24. Watkiss $P$, Gobiet A, Jacob D, Kjellstrom $E_{\text {, }}$ Kotova L, Landgren O, Lenderink $G$, Mendlik $T$, Nikulin G, Sobolowski S, Teichmann $C$ Vautard $R$. IMPACT2C Policy Update on $2{ }^{\circ} \mathrm{C}$ Warming; Climate Service Center: Hamburg, Germany. 2013. DOI: 10.1016/j.cliser.2017.03.005.

25. EEA. Mapping the Impacts of Natural Hazards and Technological Accidents in Europe: An Overview of the Last Decade; European Environment Agency: Copenhagen, Denmark. 2010;13:60-2. DOI: 10.2800/62638.

26. Guha-Sapir D, Below R, Hoyois P. EM-DAT The International Disaster Database, Centre for Research in Epidemiology of Disasters-CRED. 2011 October 6. Available from: http://www. emdat.be.

27. Finlay S, Moffat A, Gazzard R, Baker D, Murray V. Health impacts of wildfires. PLoS Curr. 2012 Nov 2;4. DOI: 10.1371/4f959951cce2c.

28. Adamis $D$, Papanikolaou $V$, Mellon $R C$, Prodromitis G, Tyrovola K, Kyriopoulos J. P-1035 Long-term psychological effects of a wildfire disaster in Greece. Eur. Psychiatry. 2012;27:1. DOI: 10.1016/S0924-9338(12)75202-1.

29. Slezakova K, Morais S, Pereira MC. Forest fire in Northern region of Portugal: Impact on PM levels. Atmos. Res. 2013:127:148-53. DOI: 10.1016/j.atmosres.2012.07.012.

30. Delfino RJ, Brummel S, Wu J, Stern H, Ostro B, Lipsett $M$, et al. The relationship of respiratory and cardiovascular hospital admissions to the southern California wildfires of 2003. Occup Environ Med. 2009;66:189-97. DOI: 10.1136/oem.2008.041376. 
31. Jaffe DA, Wigder NL. Ozone production from wildfires: a critical review. Atmos

Environ. 2012:51:1-10.

DOI: 10.1016/j.atmosenv.2011.11.063

32. Johnston FH, Henderson $S B$, Chen $Y$, Rand erson JT, Marlier M, Defries RS et al. Estimated global mortality attributable to smoke from landscape fires. Environ Health Perspect. 2012;120:695-701. DOI: 10.1289/ehp. 1104422.

33. Youssouf H, Liousse C, Roblou L, Assamoi EM, Salonen RO, Maesano C. Quantifying wildfires exposure for investigating health-related effects. Atmos. Environ. 2014;97:239-51. DOI: 10.1016/j.atmosenv.2014.07.041.

34. Shaposhnikov D, Revich B, Bellander T, Bedada GB, Bottai M, Kharkova T, Kvasha E, Lezina E, Lind T, Semutnikova E et al. Mortality related to air pollution with the Moscow heat wave and wildfire of 2010. Epidemiology. 2014;25:359-64 DOI: 10.1097/EDE.0000000000000090.

35. Khabarov N, Krasovskii A, Obersteiner M, Swart R, Dosio A, San-Miguel-Ayanz J, Durrant T, Camia A, Migliavacca M. Forest fires and adaptation options in Europe. Reg. Environ. Chang. 2014. DOI: 10.1007/s10113-014-0621-0.

36. Tryland I, Myrmel M, Østensvik Ø, Wennberg $A C$, Robertson LJ. Impact of rainfall on the hygienic quality of blue mussels and water in urban areas in the Inner Oslofjord, Norway. Mar. Pollut. Bull. 2014;85:42-9.

DOI: 10.1016/j.marpolbul.2014.06.028.

37. Jakubicka T, Vos F, Phalkey R, Marx M, Guha-Sapir D. Health Impacts of Floods in Europe. Data Gaps and Information Needs from a Spatial Perspective; MICRODIS: Heidelberg, Germany. 2010. Available from: http://www. microdis-eu.be/sites/default/files/D3.2.5 \%20 \%20study \%20report \%20on \%20the \%20 impact \%20 of \%20natural \%20disasters \%20in $\% 20$ Germany \%20and \%20other \%20selected $\% 20$ European \%20countries_1.pdf.

38. Vasconcelos P. Flooding in Europe:

A brief review of the health risks.

Eurosurveillance. 2006;11:2947.

DOI: 10.2807/esw.11.16.02947-en.

39. WHO. Floods in the WHO European Region: Health Effects and Their Prevention; WHO: Copenhagen, Denmark. 2013. Available from: http://www.euro.who.int/ data/assets/pdf file/0020/189020/e96853.pdf.

40. Suk JE, Ebi KL, Vose D, Wint W, Alexander N, Mintiens $K$, Semenza JC. Indicators for tracking European vulnerabilities to the risks of infectious disease transmission due to climate change. Int. J. Environ. Res. Public Health. 2014;11:2218-35. DOI: 10.3390/ijerph110202218.

41. Morand S, Owers KA, Waret-Szkuta A McIntyre KM, Baylis M. Climate variability and outbreaks of infectious diseases in Europe. 2013:3:1774. DOI: 10.1038/srep01774.

42. WHO. Regional Office for Europe Information leaflet: Malaria in the WHO European Region (English); WHO: Geneva, Switzerland.2015. Available from: http://www.euro.who.int/en/ publications/abstracts/malaria-in-the-whoeuropean-region.-on-the-road-to-elimination20002015.-summary-2018.

43. Lau CL, Smythe LD, Craig SB, Weinstein P. Climate change, flooding, urbanisation and leptospirosis: Fuelling the fire? Trans. R. Soc. Trop. Med. Hyg. 2010;104:631-8. DOI: 10.1016/j.trstmh.2010.07.002.

44. Kovats RS, Edwards SJ, Hajat S, Armstrong BG, Ebi KL, Menne B. The effect of temperature on food poisoning: A time-series analysis of salmonellosis in ten European countries. Epidemiol. Infect. 2004;132:443-53. DOI: 10.1017/s0950268804001992.

45. Faustini A, Stafoggia M, Berti G, Bisanti L, Chiusolo M, Cernigliaro A, Mallone S, Primerano $R$, Scarnato $C$, Simonato $L$ et al. The relationship between ambient particulate matter and respiratory mortality: A multi-city study in Italy. Eur. Respir. J. 2011;38:538-47. DOI: 10.1183/09031936.00093710.

46. Zhang $Y, B i P$, Hiller JE. Climate change and disability-adjusted life years. J Environ Health. 2007:70(3):32-6. Available from: https://www. ncbi.nlm.nih.gov/pubmed/17941401

47. Basu R, Malig B, Ostro B. High ambient temperature and the risk of preterm delivery. Am J Epidemiol. 2010;172(10):1108-17. DOI: 10.1093/aje/kwq170.

48. Kent ST, McClure LA, Zaitchik BF, Smith TT, Gohlke JM. Heat waves and health outcomes in Alabama (USA): the importance of heat wave definition. Environ Health Perspect. 2014;122(2):151-8. DOI: 10.1289/ehp.1307262.

49. Schifano P, Lallo A, Asta F, De Sario M, Davoli $M$, Michelozzi P. Effect of ambient temperature and air pollutants on the risk of preterm birth, Rome 2001-2010. Environ Int. 2013;61:77-87. DOI: 10.1016/j.envint.2013.09.005.

\section{Deschenes $O$, Greenstone $M$.}

Climate change, mortality, and adaptation: evidence from annual fluctuations in weather in the US. American Economic Journal: Applied Economics. 2011 October 3:152-85. DOI: 0.1257/app.3.4.152.

51. Haines A, Kovats RS, Campbell-Lendrum D, Corvalan C. Climate change and human health: impacts, vulnerability, and mitigation. Lancet. 2006;367(9528):2101-9. DOI: 10.1016/S0140-6736(06)68933-2.

52. Sellman J, Hamilton JD. Global climate change and human health. Minn Med. 2007;90:47-50.

53. Lozano R, Naghavi M, Foreman K, Lim S, Shibuya K, Aboyans $V$ et al. Global and regional mortality from 235 causes of death for 20 age groups in 1990 and 2010: a systematic analysis for the Global Burden of Disease Study 2010. Lancet 2012;380:2095-128. DOI: 10.1016/S0140-6736(12)61728-0.

54. Pinkerton KE, Rom WN, Akpinar-Elci $M$ et al; American Thoracic Society Environmental Health Policy Committee. An official American Thoracic Society workshop report: climate change and human health. Proc Am Thorac Soc. 2012;9(1):3-8. DOI: 10.1513/pats.201201-015ST.

55. US Environmental Protection Agency. Health risk and exposure assessment for ozone. Second external review draft. 2014. Available at: www.epa.gov/ttn/naaqs/standards/ozone/ data/20140131 healthrea.pdf. Accessed September 18, 2014

56. WHO. Atlas of health and climate. 2014. Available at: www.who.int/globalchange/pub- lications/atlas/report/en/. Accessed September 22. 2014.

57. Fleury $M$, Charron DF, Holt JD, Allen $O B$, Maarouf $A R$. A time series analysis of the relationship of ambient temperature and common bacterial enteric infections in two Canadian provinces. Int J Biometeorol. 2006;50(6):385-91. DOI: $10.1007 / \mathrm{s} 00484-006-0028-9$.

58. Luber G, Knowlton K, Balbus J, et al. Chapter 9: Human Health. In: Melillo JM, Richmond TC, Yohe GW, eds. Climate Change Impacts in the United States: The Third National Climate Assessment. Washington, DC: US Global Change Research Program. 2014:220-56. DOI: $10.7930 / J 0 Z 31$ WJ2.

59. Grigoriev $\mathrm{Cl}$. Investigation of the relationship between the vegetative regulation of the human body and the heliometofactors. Natural almanac. 2008;(11):69-72. Available from: http://www.kspu.edu/FileDownload. ashx/ \%D0 \%90 \%D0 \%BB \%D1 \%8C \%D0 \%BC \%D0 \%B0 \%D0 \%BD \%D0 \%B0 \%D1 \%85_\%20 2008_11.pdf?id=8b9bf997-4009-49a9-b6d63b2f52011872.

60. Vadzyuk SN, Ratynska OM, Oleksiuk LF, Vadzyuk JS. Features of mental capacity of adolescents: psycho- and ecophysiological aspects. Ternopil: Ukrmedkniga. 2018:144p.

61. Vadzyuk SN, Vandjura VJ, Denefil OV, Papinko IY, Ratynska OM. Features of the development of the body of students and students of the city of Ternopil. Ternopil:Volia. 2005:187p

62. Vadzyuk SN, Volkova NM, Mikula MM Tserkovniuk RG. Influence of weather on the psycho-physiological state of healthy people. Ternopil: Jura.1998:147p.

63. Vadzyuk SN, Kurko YV. Features of productive performance of freestyle swimmers in different meteorological situations. Bulletin of scientific research. 2005;1:108-110. Available from: http://nbuv.gov.ua/UJRN/ vndt_2005_3_22.

64. Ren $W$, Tian $H$, Tao B, Chappelka A, Sun $G$ Lu C, Liu M, Chen G, Xu X. Impacts of tropospheric ozone and climate change on net primary productivity and net carbon exchange of China's forest ecosystems. Global Ecology and Biogeography. 2011 May 1;20(3):391-406. DOI: 10.1111/j.1466-8238.2010.00606.x.

65. Vadzyuk SN, Ziatkovska NY. Physiology of external respiration: examination methods, age characteristics. Ternopil. 2001:148p.

66. Vadzyuk SN, Ziatkovska NY, Papinko IY., Volkova NM. Hemodynamics in different types of weather. Ternopil: Volia. 2003:38p.

67. Vadzyuk SN, Shmata RM, Lozina LB. Influence of vestibular load on the circulatory system in different types of weather. Scientific and practical journal "Art of Medicine". 2019:4(12):36-44. DOI: 10.21802/artm.2019.4.12.36.

68. Rosenzweig C, Parry ML. Potential impact of climate change on world food supply. Nature. 1994 Jan;367(6459):133-93. DOI: $10.1038 / 367133 a 0$.

69. Langley JA, Megonigal JP. Ecosystem response to elevated CO 2 levels limited by nitrogen-induced plant species shift. Nature. 2010 Jul 466(7302):85. DOI: 10.1038/nature09176. 


\section{Медико-социамьные аспекты глобального потепления}

\section{В. И. Цимбалюк' , С. Н. Вадзюк²}

${ }^{1}$ Национальная академия медицинских наук Украины, ул. Гериена, 12, Киев 04050, Украина

${ }^{2}$ Тернопольский национальный медицинский университет им. И. Я. Горбачевского МОЗ Украины, Майдан Воли, 1, Тернополь 46001, Украина

$\Pi$ роблема глобального потепления в последнее время становится все более актуальной. По данным Всемирной метеорологической организации, последние четыре года стали самыми теплыми в истории столетних наблюдений, что является ярким свидетельством изменения климата. В статье приведены факты все чаще наблюдаемых разнообразных климатических катаклизмов (грозы, тайфуны, штормы, наводнения и др.). Причиной изменений климата авторы считают накопление в атмосфере парниковых газов. При таких условиях наиболее невыгодное положение занимают города, количество населения которых постоянно растет. Они страдают от так называемого «эффекта теплового острова». В публикации изложено, каким образом изменение климата влияет на жизнь обитателей планеты и ее продолжительность. Особое внимание авторы уделяют детям, определяя эту категорию как наиболее чувствительную к влиянию глобальных изменений климата.

Последствия изменения климата формируют определенные погодные ситуации, соответствующий погодный фон. Авторы статьи, пользуясь одной из классификаций погоды, установили частоту, с которой встречаются ее различные типы на протяжении 25 лет в условиях города Тернополя. Оказалось, что в условиях глобального потепления существенно возросло количество дней с III типом погоды. Поэтому при постановке вопроса о влиянии современных климатических условий на здоровье людей целесообразно установить изменения жизнедеятельности в этих метеорологических ситуациях. Оценка психоэмоционального состояния молодых людей показала ухудшение их настроения, психической активности, интереса к выполнению умственной работы, возрастание тревожности при III типе погоды. Тогда же ухудшались внимание, память, мышление, возрастал латентный период сложной зрительно-моторной реакции. При метеоситуации III типа было выявлено снижение физической работоспособности пловцов. Их дыхательная система реагировала уменьшением ее резервных возможностей, сокращением проходимости бронхов, снижением насыщения крови кислородом. При этом наблюдалось падение функциональных резервов сердечно-сосудистой системы на фоне дисбаланса автономной регуляции деятельности сердца. Установлено повышение вестибулярной чувствительности. Исходя из полученных результатов, авторы делают вывод, что изучение влияния глобального потепления на организм людей следует проводить с учетом не только метеорологического фактора, температурного, но и целого комплекса факторов в виде типов погоды.

В статье также рассмотрен важный медико-социальный вопрос прогнозирования продовольственной безопасности, обеспечения питьевой водой.

Ключевые слова: глобальное потепление, типы погоды, здоровье.

Для цитирования: Цимбалюк ВИ, Вадзюк СН. Медико-социальные аспекты глобального потепления. Журнал Национальной академии медицинских наук Украинь. 2019;25(4):439-47. DOI: 10.37621/JNAMSU-2019-4-439-447.

Статья поступила в редакцию 28 октября 2019 | Направлена на рецензирование 22 ноября 2019 | Принята в печать 24 декабря 2019 